Original article

\title{
Allelic and phenotypic characterization of CYP2D6 and its encoded P450 cytochrome enzyme in a serie of Spanish type 1 Gaucher disease patients
}

\author{
Laura López de Frutos $^{\mathrm{a}, \mathrm{b}, *}$, Pilar Alfonso ${ }^{\mathrm{a}}$, Carlos Lahoz ${ }^{\mathrm{a}, \mathrm{b}}$, Pilar Irún ${ }^{\mathrm{c}}$, Pilar Giraldo ${ }^{\mathrm{b}}$ \\ a Instituto de Investigación Sanitaria Aragón (IIS Aragón), Zaragoza, Spain \\ ${ }^{\mathrm{b}}$ Fundación para el Estudio y la Terapéutica de la Enfermedad de Gaucher y Otras Lisosomales (FEETEG), Zaragoza, Spain

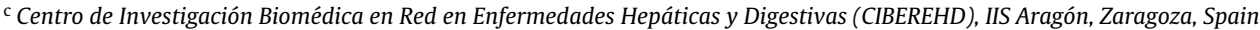

\section{A R T I C L E I N F O}

\section{Article history:}

Received 22 October 2019

Accepted 30 January 2020

Available online $\mathrm{xxx}$

\section{Keywords:}

Type 1 Gaucher disease

CYP2D6 gene

P450 cytochrome

Spanish genotype

\begin{abstract}
A B S T R A C T
Background: Cytochrome p450 is the main drug metabolic pathway. CYP2D6 is a highly polymorphic gene that encodes a cytochrome p450 enzyme with three activity levels: null, reduced and normal. Apart from another type of mutations CYP2D6 can suffer duplications and deletions of the entire gene. This is the pathway to metabolize one of the Gaucher disease treatments, whose dose administration is regulated according to the metabolizer phenotype, this being one of the administration limitations.

objectives: The aim of this paper is to evaluate the allelic frequencies and the metabolizer status of Gaucher type 1 patients in the Spanish population and compare it with the general Spanish population and other Gaucher disease groups.

Methods: In this study, 109 type 1 Gaucher disease patients were analyzed with the XTAG ${ }^{\circledR}$ CYP2D6 kit to identify the CYP2D6 gene alleles.

Results: We observed that eighty-seven patients could be classified as extensive, 14 as intermediate, 6 as poor and 2 as ultra-rapid metabolizers. The allelic duplication frequency is $5.5 \%$ and deletion is $4.5 \%$. The most common allele is wild-type and the second is the null * 4 allele. Intermediate phenotype frequency is higher than expected $(p<0.05)$.

Conclusions: Our Spanish GD series shows an unexpected distribution of some alleles and phenotypic metabolizer status, in contrast to that previously reported in the Spanish population.
\end{abstract}

(C) 2020 Elsevier España, S.L.U. All rights reserved.

\section{Caracterización alélica y fenotípica del gen y la enzima Cyp2d6 en una cohorte de pacientes españoles con enfermedad de Gaucher tipo 1}

\section{R E S U M E N}

Introducción: La superfamilia citocromo P450 es la principal vía de metabolización de fármacos. Uno de los genes que la componen, CYP2D6, es altamente polimórfico y puede producir enzimas con 3 niveles de actividad: nula, reducida o normal. Además de presentar variantes puntuales, este gen puede sufrir duplicidad o deleción. CYP2D6 es la principal vía de metabolización del último tratamiento aprobado para la enfermedad de Gaucher, cuya administración y dosificación depende del estado metabolizador de CYP2D6.

Objetivos: El objetivo de este trabajo es evaluar la frecuencia alélica y la distribución de fenotipos metabolizadores en una serie de pacientes españoles con enfermedad de Gaucher, y compararla con los datos publicados para población española general y con otros grupos de pacientes de Gaucher. Métodos: Se han genotipificado 109 pacientes con enfermedad de Gaucher tipo 1 mediante el sistema XTAG ${ }^{\circledR}$ CYP2D6.

Abbreviations: CYPIID6, cytochrome P450 2D6 enzyme; PharmVar, pharmacogene variation consortium; NM, normal metabolizer; IM, intermediate metabolizer; PM, poor

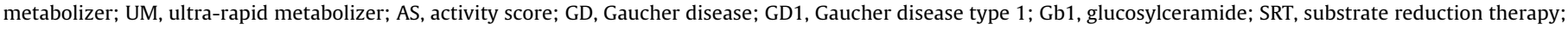
CG1, control group 1; CG2, control group 2 .

* Corresponding author.

E-mail address: llopezdefrutos.uit@gmail.com (L. López de Frutos). 
Resultados: Nuestra población se distribuye en 87 pacientes con un fenotipo metabolizador normal, 14 intermedios, 6 lentos y 2 ultrarrápidos. La frecuencia de la duplicación y deleción del gen es del 5,5 y $4,5 \%$, respectivamente. El alelo más común es la forma nativa de la proteína y el segundo el alelo * 4 que codifica para una proteína inactiva. La frecuencia de fenotipos intermedios es superior a la esperada en población general $(\mathrm{p}<0,05)$, principalmente a causa de un incremento en la frecuencia de los alelos que codifican enzimas con actividad reducida $(\mathrm{p}<0,05)$.

Conclusiones: El grupo español de pacientes con enfermedad de Gaucher muestra una distribución alélica y fenotípica diferente a la esperada para la población española.

(c) 2020 Elsevier España, S.L.U. Todos los derechos reservados.

\section{Introduction}

The pharmacodynamics is one of the most important characteristics to know the safety and efficacy of drugs used in clinical practice. It is regulated by its absorption, distribution and elimination process. Drug metabolism includes their oxidation by cytochrome enzymes. ${ }^{1}$ Cytochrome P450 superfamily is a group of oxidases involved in drug metabolism and many other cellular pathways. There are 18 mammalian cytochrome P450 families, which includes 57 human genes, but eleven enzymes are the most important ones for metabolizing drugs, including cytochrome P450 2D6 and $3 \mathrm{~A} 4 .^{2}$

The cytochrome P450 2D6 (CYPIID6; Uniprot code P10635) is an oxidase, member of $\mathrm{P} 450$ cytochrome superfamily, involved in the hepatic clearance of approximately $20 \%$ of the most common drugs, including codeine or paracetamol. ${ }^{1}$ This enzyme is encoded by CYP2D6 gene (MIM*608902), it is a highly polymorphic gene with 146 alleles according to the pharmacogene variation consortium (PharmVar) ${ }^{3}$ which presents a differential allele distribution among populations. ${ }^{4}$ Point mutations, deletions, insertions, gene rearrangements, and duplication or deletion of the entire gene are responsible for different metabolizer phenotypes. According to the enzyme activity these fall into four categories: poor metabolizers (PM) without enzymatic activity; intermediate metabolizers (IM) those with a non-functional allele in combination with a normal activity one; extensive or normal metabolizers (NM) with a normal activity on both alleles; and ultra-rapid metabolizers (UM) those with more than two functional alleles. 5,6

Nowadays this classification is being replaced by an activity score (AS). ${ }^{7}$ Those alleles that encode a protein without enzymatic activity obtain a 0 score, those for enzymes with reduced activity are punctuated with 0.5 and the normal activity encoders obtain 1 point. The subject alleles sum provided the AS between 0 (two null alleles) and $>3$ (subjects with at least three normal alleles). The consensus among experts is clear to define $\mathrm{AS}=0$ as $\mathrm{PM}, \mathrm{AS}=0.5$ as IM, AS $=1.5$ or 2 as NM and AS $>3$ as UM, but the classification of 1 and 2.5 scores is not clear and experts are divided. ${ }^{5}$

Gaucher disease (GD), the most frequent lysosomal storage disorder, has been classically subdivided into three clinical phenotypes, being type 1 phenotype the most commonly found (GD1; MIM\#230800). ${ }^{8}$ GD is an inherited autosomal recessive disease, that arises from damaging variants in the GBA1 gene $\left(\mathrm{MIM}^{*} 606463\right)$. The gene includes 11 exons and it is located on chromosome 1 (1q21-22). On July'18 the professional "Human Gene Mutation Database" included 472 pathogenic variants related to the disease, but only 4 of them are responsible over 90\% of GD1 patients in Ashkenazi Jews and over 50\% in non-Jewish patients. ${ }^{8,9}$

GBA1 gene encodes a lysosomal enzyme named acid $\beta$-glucosidase, responsible for glucosylceramide (Gb1) hydrolysis. Enzymatic malfunction induces $\mathrm{Gb} 1$ accumulation in the macrophagic mononuclear system cells which are the responsible for the most frequent or common clinical manifestations of GD: splenomegaly, hepatomegaly, growth delay and bone disease. ${ }^{8}$
The treatment with recombinant enzyme began in 1991. Nowadays it consists of intravenous infusions with a 2-week frequency. Despite not being curative, it has been proved that it is a safe and efficient treatment and improves patients life quality. ${ }^{10}$ Another treatment option is the substrate reduction therapy (SRT), based on the inhibition of the enzyme glucosylceramide synthase with the purpose of reducing the Gb1 synthesis. There are two drugs approved for GD and based on SRT, the first approved in 2004 is an iminosugar (Miglustat, Zavesca ${ }^{\circledR}$ ), and its analogy with the glucosyl group allows it to inhibit the enzyme by mimetic competition, ${ }^{11}$ and the second one is a ceramide analogous (Eliglustat, Cerdelga ${ }^{\circledR}$ ) approved in 2015 as GD1 treatment. ${ }^{12}$

Eliglustat, a tartrate salt analogous to 1-phenyl-2decanoylamino-3-morpholino-1-propanol is one of the drugs metabolized through CYPIID6 enzyme. It is a glucosylceramide synthase inhibitor that induces a glucosylceramide production reduction, avoiding its accumulation. It is therefore approved by the European Union and the United States as a SRT to manage type 1 Gaucher disease (GD1) patients ${ }^{13}$ and, it is mandatory to genotype CYP2D6 to determinate its metabolizing status before start any treatment with it. ${ }^{14}$

Despite non-inductors for CYPIID6 have been described, it is necessary to identify functional differences in the cytochrome activity to avoid clinical issues due to pharmacological interactions, ${ }^{1,15}$ as well as avoid high drug doses such that the patient cannot metabolize properly. The aim of this project is to analyze the allelic status of CYP2D6 and the corresponding phenotype on CYPIID6 on a Spanish GD1 patients' population.

\section{Methods}

\section{Patients}

We have studied 109 patients (GD-S group), older than 18 years of age, with confirmed enzymatic and genetic diagnosis of GD, and a clinical classification for type 1 included in the Spanish Gaucher disease Registry. The study design was approved by the institutional board of FEETEG foundation. All individuals were provided with the written informed consent and the study was conducted in accordance with the principles stated in the Declaration of Helsinki - Ethical Principles for Medical Research Involving Human Subjects, Helsinki, Finland, 1964, and as amended in Fortaleza, Brazil, 2013. The exclusion criteria were the inclusion on the clinical trial ENCORE.

\section{GBA1 sequencing}

The GBA1 gene was amplified according to the previously published. ${ }^{16}$ To summarize it, a long-chain PCR using specific primers of the functional GBA1 gene and subsequent nested PCR of each exonic region were performed. Products were sequenced by capillary electrophoresis and analyzed with the Variant Report 
v.1 software. Results were compared to the reference sequence available in the GeneBank database (NG_009783.1).

\section{CYP2D6 genotyping}

The allele identification of the CYP2D6 gene (GeneBank database reference: NG_008376.3) was done according to the xTAG ${ }^{\circledR}$ CYP2D6v3 (Luminex Corporation, Texas, USA) manufacturer instructions.

This kit analyzes 19 genetic variants and the presence of genetic deletions or duplications that allowed us to identify 17 alleles and establish a metabolizer phenotype for all evaluated patient.

Briefly, DNA was first isolated and purified from whole blood using a commercial extraction kit, and according to the manufacturer instructions. A UV 260/280 ratio purity of at least 1.5 is necessary to perform the genotyping assay. Gene duplication and 19 SNPs were amplified by multiplex PCR and cleaned by enzymatic purification. Multiplex allele-specific primer extension was then performed, followed by a bead hybridization. Finally, a reporter molecule was added, washed and analyzed on XMAPTM equipment.

All reactions included a negative control and a control sample for each metabolizer status. All patients with gene duplication were analyzed twice.

\section{CYP2D6 genotype-phenotype correlation}

The correlation between genotype and phenotype has been made by the allelic correlation, establishing 4 activity groups: NM, PM, IM and UM phenotypes and, according to the activity score (AS) published by Gaedigk in 2008. , $^{\text {, }}$

Each allele has an assigned score between 0 and 2, and the sum of both alleles provides an AS that allow us to classify the patients between 0 predicting poor metabolizers, and $>2$ predicting ultrarapid metabolizers.

The correlation between the AS and the classical phenotype assignation has been done defining poor metabolizer as those with $\mathrm{AS}=0$, intermediate metabolizer with $\mathrm{AS}=0.5$, normal metabolizer as those with AS between 1 and 2 and ultra-rapid metabolizers as those with activity score $>3$.

\section{Control data analysis}

Three control dataset were obtained from the literature.

The first one (Control group 1; CG1) was obtained from the Spanish reports included on the Pharmgkb Database (https://www.pharmgkb.org/page/cyp2d6RefMaterials). This database includes 11 papers published between 2004 and 2017, but only 5 of them analyze all the alleles, so only these have been considered to prepare our control population dataset. ${ }^{17-21}$

The second one (Control group 2; CG2) was obtained from one of the most recent papers about the genotypes and phenotypes CYP2D6 frequencies. This report includes 6060 healthy subjects, 1537 of them Iberian (1081 Spanish population). ${ }^{22}$ As this report does not analyze *9 allele and it is characterized by one specific variant, its general frequency has been obtained from the Spanish Variant Server. ${ }^{23}$

The third group (Control group 3; ENCORE) was obtained from clinical trial ENCORE published data. ${ }^{24}$ This group only includes metabolizer status information because allelic and AS information is not available.

\section{Statistical analysis}

The AS, metabolizer phenotype and allele frequency variability with the control groups were analyzed by chi-square test,
Table 1

GBA1 genotypes in our sample. GBA1 genotype frequency. Compound heterozygous with the variants NM_000157.3:c.1226A $>\mathrm{G}$ and c.1448T $>\mathrm{C}$ is the most common, follow by the homozygous state for the variant NM_000157.3:c.1226A>G. Other 30 variants have been found on combination with the c.1226A>G, half of it only has been observed in one patient.

\begin{tabular}{|c|c|c|}
\hline & TOTAL (109) & $\begin{array}{l}\text { Frequency } \\
\text { (\%) }\end{array}$ \\
\hline \multicolumn{3}{|l|}{ GBA1 damaging variants (NM_000157) } \\
\hline$[$ c. $1226 \mathrm{~A}>\mathrm{G}+\mathrm{c} .1448 \mathrm{~T}>\mathrm{C}]$ & 38 & $34.86 \%$ \\
\hline$[\mathrm{c} .1226 \mathrm{~A}>\mathrm{G}+\mathrm{c} .1226 \mathrm{~A}>\mathrm{G}]$ & 12 & $11.01 \%$ \\
\hline$[\mathrm{c} .1226 \mathrm{~A}>\mathrm{G}+\mathrm{c} .84 \mathrm{dupG}]$ & 5 & $4.59 \%$ \\
\hline [c.1226A>G + c.1263_1317del55] & 3 & $2.75 \%$ \\
\hline$[c .1226 \mathrm{~A}>\mathrm{G}+\mathrm{c} .517 \mathrm{~A}>\mathrm{C}]$ & 3 & $2.75 \%$ \\
\hline [c.1226A>G + c.1093G >A + c.679_680delAAinsTC] & 3 & $2.75 \%$ \\
\hline$[c .1226 \mathrm{~A}>\mathrm{G}+\mathrm{c} .700 \mathrm{G}>\mathrm{T}]$ & 3 & $2.75 \%$ \\
\hline$[\mathrm{c} .1226 \mathrm{~A}>\mathrm{G}+\mathrm{c} .721 \mathrm{G}>\mathrm{A}]$ & 3 & $2.75 \%$ \\
\hline$[c .1226 \mathrm{~A}>\mathrm{G}+\mathrm{c} .1601 \mathrm{G}>\mathrm{A}]$ & 3 & $2.75 \%$ \\
\hline$[\mathrm{c} .1226 \mathrm{~A}>\mathrm{G}+\mathrm{c} .1289 \mathrm{C}>\mathrm{T}]$ & 3 & $2.75 \%$ \\
\hline$[\mathrm{c} .1226 \mathrm{~A}>\mathrm{G}+\mathrm{c} .107 \mathrm{G}>\mathrm{A}]$ & 3 & $2.75 \%$ \\
\hline [c.1226A>G + c.1439_1445del7] & 2 & $1.83 \%$ \\
\hline$[c .1226 \mathrm{~A}>\mathrm{G}+\mathrm{c} .1090 \mathrm{G}>\mathrm{T}]$ & 2 & $1.83 \%$ \\
\hline$[c .1226 \mathrm{~A}>\mathrm{G}+\mathrm{c} .455 \mathrm{G}>\mathrm{A}]$ & 2 & $1.83 \%$ \\
\hline$[\mathrm{c} .1226 \mathrm{~A}>\mathrm{G}+\mathrm{c} .256 \mathrm{C}>\mathrm{T}]$ & 2 & $1.83 \%$ \\
\hline$[c .1226 \mathrm{~A}>\mathrm{G}+\mathrm{c} .604 \mathrm{C}>\mathrm{T}]$ & 2 & $1.83 \%$ \\
\hline [c.1226A>G + RecNcil] & 2 & $1.83 \%$ \\
\hline $15 \times[c .1226 \mathrm{~A}>\mathrm{G}++$ Other $]$ & 15 & $13.76 \%$ \\
\hline [Other + Other] & 3 & $2.75 \%$ \\
\hline
\end{tabular}

considering statistically significant those $p$-values $<0.05$. All statistics were analyzed by IBM SPSS statistics v22 software.

\section{Results}

\section{Genotype and phenotype description on GD-S patients}

We analyzed 109 subjects, with a gender proportion of 1:1 (55 females and 54 males). The most common damaging variant of GBA1 is NM_000157:c.1226A>G (NP_000148:p.Asn409Ser), it was found on 53.0\% of patients, followed by NM_000157:c.1448T>C (NP_000148:p.Leu483Pro) with a frequency of $18.0 \%$. All other found variants presented a low frequency between 2.8 and $0.5 \%$ (Table 1).

All patients were classified according to their CYPID6 metabolizer status, 87 are NM, 14 IM, 6 PM and only 2 are UM (Fig. 1A) and according to their activity score: 6 are $A S=0,13$ are $\mathrm{AS}=0.5,25$ are $\mathrm{AS}=1,18$ are $\mathrm{AS}=1.5,45$ subjects are $\mathrm{AS}=2$ and only 2 patients have an AS $>2$ (Fig. 1B). There are no significant differences in phenotype or allele distributions among patients depending on their gender. No relationship has been observed between GBA1 and CYP2D6 genotypes ( $p>0.05$ ).

Six subjects have an allele duplication, but in 3 cases it is combined with * 4 allele (it codifies for a null enzyme) and the other case is in combination with alleles that encode enzymes with reduced activity, so they cannot be considered UM despite the duplication. A total of 5 subjects show a deletion (carriers for $* 5$ allele).

The most frequent genetic variant is NG_008376.3:g.8381G $>C$ (NM_000106.5:c.1547G>C), the minor allele frequency for this variant on this study is $51.8 \%$ and it is not related to a metabolizer phenotype.

The most frequent allele in our project is the wild-type form (39.00\%), followed by the null * 4 allele (19.0\%) and the normal function ${ }^{*} 2$ allele (17.0\%). The ${ }^{*} 7,{ }^{*} 8,{ }^{*} 11,{ }^{*} 15$ alleles, that encode for non-functional proteins and ${ }^{*} 29$ which encodes a reduced activity protein, are not present in our population (Fig. 2).

At least one allele encoding for a non-functional protein is found in 53 subjects (48.6\%) and at least one for a reduced function protein in 15 patients (13.8\%). 
CYP2D6 Metabolizer Phenotype

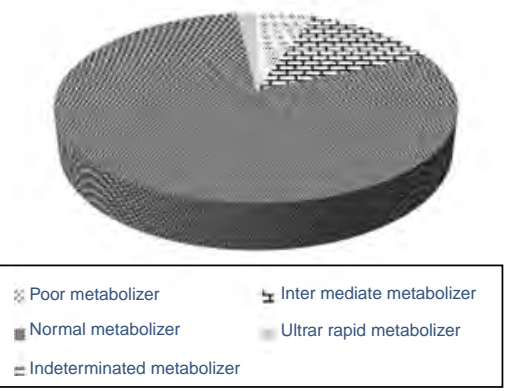

CYP2D6 Activity Score

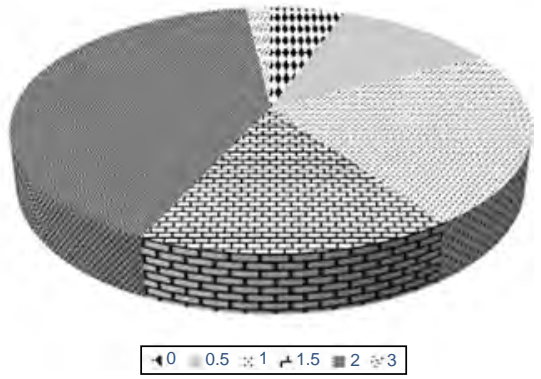

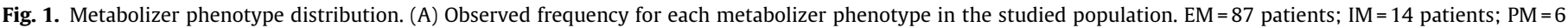

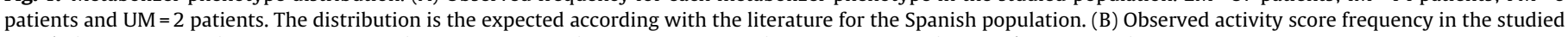
population. $\mathrm{AS}=06$ patients; $\mathrm{AS}=0.513$ patients; $\mathrm{AS}=125$ patients; $\mathrm{AS}=1.518$ patients; $\mathrm{AS}=245$ patients and $\mathrm{AS}=32$ patients .

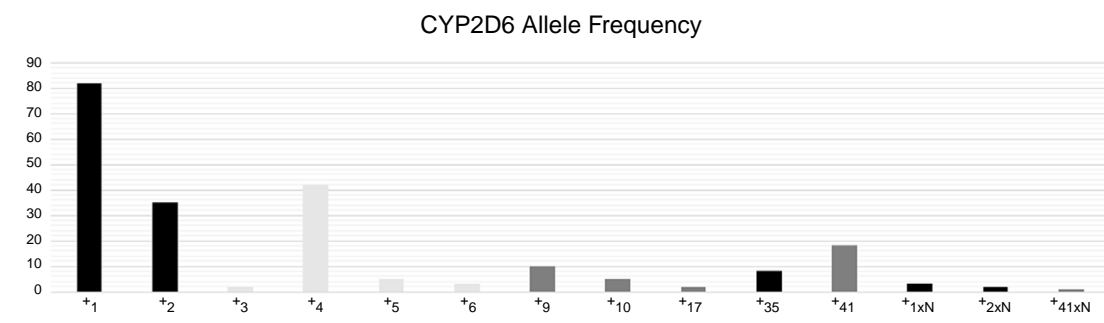

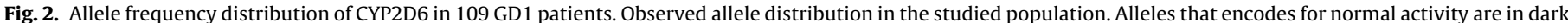

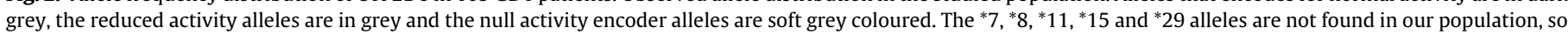
they are not represented on the figure.

Table 2

CYP2D6 variants distribution. Frequency of each analyzed variant on CYP2D6 in our population. Not all variants define an allele and some alleles need more than one variant to be defined.

\begin{tabular}{|c|c|c|c|}
\hline Allele & Variant & TOTAL (109) & Frequency (\%) \\
\hline \multicolumn{4}{|c|}{ CYP2D6 genetic variants (NM_000106.5) } \\
\hline & Duplication & 6 & $2.75 \%$ \\
\hline *5 & Deletion & 5 & $2.29 \%$ \\
\hline *2 & c. $-1584 \mathrm{C}>\mathrm{G}$ & 44 & $20.18 \%$ \\
\hline *35 & c. $31 \mathrm{G}>\mathrm{A}$ & 8 & $3.67 \%$ \\
\hline \multirow[t]{2}{*}{$* 10$} & c. $100 C>T$ & 47 & $21.56 \%$ \\
\hline & c. $124 \mathrm{G}>\mathrm{A}$ & 0 & $0.00 \%$ \\
\hline$* 15$ & c.137_138insT & 0 & $0.00 \%$ \\
\hline$* 11$ & c. $181-1 G>C$ & 0 & $0.00 \%$ \\
\hline$* 17$ & c. $320 \mathrm{C}>\mathrm{T}$ & 2 & $0.92 \%$ \\
\hline \multirow[t]{2}{*}{ *29 } & c. $406 \mathrm{G}>\mathrm{A}$ & 0 & $0.00 \%$ \\
\hline & c. $408 \mathrm{G}>\mathrm{C}$ & 112 & $51.38 \%$ \\
\hline *6 & c.454delT & 3 & $1.38 \%$ \\
\hline$* 8$ & c. $504 \mathrm{C}>\mathrm{T}$ & 2 & $0.92 \%$ \\
\hline *4 & c. $506-1 G>A$ & 42 & $19.27 \%$ \\
\hline *3 & c.775delA & 2 & $0.92 \%$ \\
\hline$* 9$ & c.841_843delAAG & 10 & $4.59 \%$ \\
\hline *2 & c. $886 C>A$ & 66 & $30.28 \%$ \\
\hline$* 7$ & c. $971 \mathrm{~A}>\mathrm{C}$ & 0 & $0.00 \%$ \\
\hline$* 41$ & c. $985+39 G>A$ & 19 & $8.72 \%$ \\
\hline$* 29$ & c. $1012 \mathrm{G}>\mathrm{A}$ & 0 & $0.00 \%$ \\
\hline$* 2$ & c. $1457 \mathrm{G}>\mathrm{C}$ & 113 & $51.83 \%$ \\
\hline
\end{tabular}

The most common genetic variant related with a non-functional protein is NM_000106.5:c.506-1G>A which defines the *4 allele founded in $19.00 \%$ of cases, while the most common for a reduced functional protein is NM_0001065:c.841delAAG, defining the ${ }^{*} 9$ allele founded in $5.00 \%$ of cases (Table 2 ).

\section{Comparison with control groups}

The source used to design CG1 and ENCORE datasets does not allow us to classify these groups according to the activity score, so we are not able to make this comparison.
The comparison study of the distribution of the metabolizer phenotype between our GD-S population and the CG1 showed significant statistically differences on the frequency of the IM phenotype ( $p$-value $=0.028$ ), being this phenotype much more common in our GD-S population than in the CG1 (12.8\% vs $7.2 \%)$.

The allele frequencies also showed an alteration on the distribution, the frequency of * 2 allele is lower than expected $(16.1 \%$ vs $27.8 \%$ ), the opposite was found for the ${ }^{*} 35$ allele which is higher than expected (3.7\% vs $1.7 \%)$. That differences are statistically significances ( $p$-value $=0.001$ and 0.044 , respectively). In addition, alleles that encodes for a protein with a reduced function shown an unexpected distribution being the frequency of ${ }^{*} 6$ and ${ }^{*} 41$ alleles on GD-S patients higher than in the CG1 $(1.4 \%$ vs $0.3 \%$ and $8.3 \%$ vs $4.1 \%$ respectively). Those differences are, again, statistically significant ( $p$-value $=0.045$ and 0.044 , respectively).

When GD patients are compared with the CG2 we obtain similar results. In this case we could analyze the activity score frequency, and we observed than $\mathrm{AS}=0.5$ showed statistically significant differences between both groups ( $p$-value $=0.003$ ), being its frequency double on GD patients than in the control group (11.93\% vs 5.56\%). As expected, due to the AS distribution, the frequency of the IM phenotype was higher on GD patients than in CG2 $(12.84 \%$ vs $5.56 \%$; $p$-value $=0.001)$. On this group the allelic distribution showed statistically significant differences in relation with the reduced activity enzyme encoders ${ }^{*} 6$ and ${ }^{*} 9$ alleles, being those higher on GD patients than on CG2 (1.4\% and $4.6 \%$ vs $0.6 \%$ and $1.5 \%$, respectively) with $p$-values $=0.045$ and 0.001 , respectively.

Comparison with other GD population, the worldwide population included on the ENCORE clinical trial, do not show statistically significant differences between the metabolizer phenotypes distribution and our GD-S group $(p>0.05)$ but shows it when compared with IM frequency in general Spanish population (CG1 $p$-value $=0.028$ and, CG2 $p$-value $=0.007$ ). 


\section{Discussion}

This is the first paper describing the genotypic and phenotypic frequency for CYP2D6 and CYPID6 on Gaucher disease population, previously only phenotypic frequencies has been reported in one paper. $^{24}$

The metabolizer phenotype frequency on this study showed differences with the previously published data for Spanish and Iberian population, observing and increased frequency on $\operatorname{IM}(12.8 \%$ vs $7.2 \%$ or $5.6 \%$, respectively) or the equivalent $A S=0.5$ ( $11.9 \%$ vs $5.6 \%$ ). Differences on UM frequencies are not statistically significant ( $p$-value $>0.05$ ) but show a tendency to be lower in the GD-S population than the Spanish or Iberian populations used as control groups ( $1.8 \%$ vs $3.3 \%$ and $5.0 \%$, respectively). ${ }^{22,25}$

The analysis of allelic frequencies of the different groups according to the encoded protein activity does not match with data recently published, with a decreased frequency for normal encoders alleles and an increased one for the reducer encoders $(p<0.01)$. A possible explanation is the reduced frequency of ${ }^{*} 2$ allele in our population, but we do not have any explanation to justify this reduction. This can be important due to the use of concomitant therapies with drugs metabolized by the same cytochrome pathway, as antihistaminic or antiarrhythmic drugs, as well as substances capable of inhibiting this metabolic pathway, which can affect harder than in other populations, raising the drug toxicity. Usually, drug administration does not take in consideration the genotype or regroup the four metabolizer phenotypes in three groups: PM with reduced doses, UM not available for the treatment and IM+NM with the standard doses. But it is necessary to consider the huge range of CYP2D6 activities included on the last group, with an AS range from 0.5 to 2 . The interpretation of CYP2D6 genotypes beyond the metabolizer phenotype extrapolation is important to understand possible drug-drug interactions and to understand and, finally prevent, adverse reactions. So, it is necessary to increase the information about patients' response to CYP2D6 metabolized therapies with every-day clinical practice reports to elucidate the importance of our results.

A tendency, although not statistically significant, has been observed on the allele duplications frequency. This is higher than previously published. ${ }^{26}$ However, due to the higher frequency of alleles that encode null or reduced functional proteins, this increase is not reflected on the UM frequency.

Our results were compared with the recently published data for Ashkenazi Jews, a population with a high frequency of damaging variants on GBA1. It is remarkably the difference between the *5 allele frequency ( $2.3 \%$ vs $1.1 \% ; p=0.001)$, as well as the higher frequency in our population for ${ }^{*} 6$ and ${ }^{*} 9$ alleles $(1.4 \%$ vs $0.8 \%$; $p=0.028$ and $4.6 \%$ vs $0.4 \% ; p=0.001$ respectively $)^{27}$ finding a higher percentage of alleles that encodes for a null o reduced activity protein in our population than in the Jewish population. This is the same difference that we found with the published Spanish population. In contrast with these results, is remarkable the concordance between our results in GD-S population and the other published GD patient's data (ENCORE clinical trial), encouraging our believe that there is any relation between GD disease and alleles that encodes for reduced activities CYP2D6 enzymes. Despite this, no correlation between GBA1 damaging variants distribution and CYP2D6 genotypes were found in our study as expected due to the genomic location for both genes.

\section{Conclusions}

In conclusion, this is the first publication that describes the genotype profile of CYP2D6 in Spanish GD population and shows some differences according to the CYP2D6 variants distribution, comparing with general Spanish population. As these differences that were not previously observed in comparison with GD patients on ENCORE clinical trial (data not shown), ${ }^{24}$ it is necessary to increase the analyzed series and perform more studies to confirm a correlation between GD and GYP2D6 genotype.

We can confirm the independence between allele frequency and gender or GBA1 genotype, but we found some disagreements with previously published data in relation to the second most frequent allele or the allele duplication frequency as well as the frequency for reduced activity encoder's alleles. This is a relevant information to consider due to the importance of this cytochrome on drug metabolism and to prevent the drug interferences, knowing that the risk of adverse effects by them is higher on patients with the lowest CYPIID6 activity.

\section{Conflict of interest}

The authors declare that they have no financial disclosures or conflict of interest.

\section{References}

1. Sychev DA, Ashraf GM, Svistunov AA, Maksimov ML, Tarasov VV, Chubarev $\mathrm{VN}$, et al. The cytochrome P450 isoenzyme and some new opportunities for the prediction of negative drug interaction in vivo. Drug Des Dev Ther. 2018; 12:1147-56

2. Zanger UM, Schwab M. Cytochrome P450 enzymes in drug metabolism: regulation of gene expression, enzyme activities, and impact of genetic variation. Pharmacol Ther. 2013;138:103-41.

3. Gaedigk A, Ingelman-Sundberg M, Miller NA, Leeder JS, Whirl-Carrillo M, Klein TE. The Pharmacogene Variation (PharmVar) consortium: incorporation of the human cytochrome P450 (CYP) allele nomenclature database. Clin Pharmacol Ther. 2018;103:399-401.

4. He Z-X, Chen X-W, Zhou Z-W, Zhou S-F. Impact of physiological, pathological and environmental factors on the expression and activity of human cytochrome P450 2D6 and implications in precision medicine. Drug Metab Rev. 2015;47:470-519.

5. Gaedigk A, Dinh J, Jeong H, Prasad B, Leeder J. Ten years' experience with the CYP2D6 activity score: a perspective on future investigations to improve clinical predictions for precision therapeutics. J Pers Med. 2018;8:15.

6. Zhou S-F. Polymorphism of human cytochrome P450 2D6 and its clinical significance: Part I. Clin Pharmacokinet. 2009;48:689-723.

7. Gaedigk A, Simon S, Pearce R, Bradford L, Kennedy M, Leeder J. The CYP2D6 activity score: translating genotype information into a qualitative measure of phenotype. Clin Pharmacol Ther. 2008;83:234-42.

8. Ferreira CR, Gahl WA. Lysosomal storage diseases. In: Metabolic Diseases: Foundations of Clinical Management, Genetics, and Pathology. IOS Press; 2017. p. 367-440.

9. Stenson PD, Mort M, Ball EV, Howells K, Phillips AD, Cooper DN, et al. The human gene mutation database: 2008 update. Genome Med. 2009.

10. Revel-Vilk S, Szer J, Mehta A, Zimran A. How we manage Gaucher Disease in the era of choices. Br J Haematol. 2018.

11. Coutinho MF, Santos JI, Alves S. Molecular sciences less is more: substrate reduction therapy for lysosomal storage disorders. Int J Mol Sci. 2016;17(7.).

12. Stirnemann J, Belmatoug N, Camou F, Serratrice C, Froissart R, Caillaud C, et al. A review of gaucher disease pathophysiology clinical presentation and treatments. Int J Mol Sci. 2017;18(441.).

13. Becquemont L. Type 1 Gaucher disease (CYP2D6-eliglustat). Therapie. 2017;72:323-6

14. The European Medicines Agency - EMA. Ficha tecnica o abstract de las caracteristicas de Cerdelga(R). Agencia Eur Medicam. 2020;1-33.

15. Shah RR, Smith RL. Inflammation-induced phenoconversion of polymorphic drug metabolizing enzymes: hypothesis with implications for personalized medicine. Drug Metab Dispos. 2015;43:400-10.

16. Giraldo P, Alfonso P, Irún P, Gort L, Chabás A, Vilageliu L, et al. Mapping the genetic and clinical characteristics of Gaucher disease in the Iberian Peninsula. Orphanet J Rare Dis. 2012;7:17.

17. Fuselli S, Dupanloup I, Frigato E, Cruciani F, Scozzari R, Moral P, et al. Molecular diversity at the CYP2D6 locus in the Mediterranean region. Eur J Hum Genet. 2004;12:916-24.

18. Menoyo A, del Rio E, Baiget M. Characterization of variant alleles of cytochrome CYP2D6 in a Spanish population. Cell Biochem Funct. 2006;24:381-5.

19. Fernández-Santander A, Gaibar M, Novillo A, Romero-Lorca A, Rubio M, Chicharro LM, et al. Relationship between Genotypes Sult1a2 and Cyp2d6 and Tamoxifen metabolism in breast cancer patients. PLoS One. 2013;8(7.).

20. Zafra-Ceres M, de Haro T, Farez-Vidal E, Blancas I, Bandres F, de Dueñas EM, et al. Influence of CYP2D6 polymorphisms on serum levels of tamoxifen metabolites in Spanish women with breast cancer. Int J Med Sci. 2013;10:932-7. 
21. Mas S, Gassó P, Torra M, Bioque M, Lobo A, González-Pinto A, et al. Intuitive pharmacogenetic dosing of risperidone according to CYP2D6 phenotype extrapolated from genotype in a cohort of first episode psychosis patients. Eur Neuropsychopharmacol. 2017:27:647-56.

22. Naranjo M-EG, Rodrigues-Soares F, Peñas-Lledó EM, Tarazona-Santos E, Fariñas $\mathrm{H}$, Rodeiro I, et al. Interethnic variability in CYP2D6 CYP2C9, and CYP2C19 genes and predicted drug metabolism phenotypes among 6060 Ibero- and native Americans: RIBEF-CEIBA consortium report on population pharmacogenomics. Omi A J Integr Biol. 2018;22:575-88.

23. Dopazo J, Amadoz A, Bleda M, Garcia-Alonso L, Alem an A, García-García F, et al. 267 Spanish exomes reveal population-specific differences in disease-related genetic variation. Mol Biol Evol. 2016;33:1205.
24. Cox TM, Drelichman G, Cravo R, Balwani M, Burrow TA, Martins AM, et al. Eliglustat maintains long-term clinical stability in patients with Gaucher disease type 1 stabilized on enzyme therapy. Blood. 2017;129:2375-83.

25. Whirl-Carrillo M, Mcdonagh EM, Hebert JM, Gong L, Sangkuhl K, Thorn CF, et al. Pharmacogenomics knowledge for personalized medicine. Clin Pharmacol Ther. 2012;92:414-7.

26. Bradford LD. CYP2D6 allele frequency in European Caucasians, Asians Africans and their descendants. Pharmacogenomics. 2002;3:229-43.

27. Zhou Y, Lauschke VM. Comprehensive overview of the pharmacogenetic diversity in Ashkenazi Jews. J Med Genet. 2018;55:617-27.

Please cite this article in press as: López de Frutos L, et al. Allelic and phenotypic characterization of CYP2D6 and its encoded P450 cytochrome enzyme in a serie of Spanish type 1 Gaucher disease patients. Med Clin (Barc). 2020. https://doi.org/10.1016/j.medcli.2020.01.032 